\title{
Damage of prestressed concrete railway sleepers and its impact on durability
}

\author{
Aidas Jokūbaitis ${ }^{1}$, Gediminas Marčiukaitis ${ }^{2}$, Juozas Valivonis ${ }^{3}$ \\ Department of Reinforced Concrete Structures and Geotechnics, \\ Vilnius Gediminas Technical University, Vilnius, Lithuania \\ E-mail: 'aidas.jokubaitis@vgtu.lt (corresponding author)
}

\begin{abstract}
Prestressed concrete railway sleepers are the most widespread sleepers due to their stiffness and high bearing capacity. They transfer train induced loads from the rails directly to the ballast and therefore are the most important part of the railway structure. As railway traffic is constantly increasing with increasing loads and additional environmental effects take place it is necessary to ensure safety of the railway. Therefore, the present study focuses on durability of prestressed concrete railway sleepers. This paper examines new sleepers and sleepers damaged during exploitation. As all sleepers were manufactured at the same time the comparison of cracking loads and bearing capacity are provided. Additionaly, a difference between chemical composition of concrete samples from new and exploited sleepers is briefly discussed. Further, possible causes of damages of exploited sleepers are analyzed.
\end{abstract}

Keywords: prestressed concrete, sleepers, rail seat, defects, service, DEF.

\section{Introduction}

Prestressed concrete elements of transport structures are affected by numerous external factors. Especially difficult conditions affect prestressed concrete railway sleepers during service. Prestressed concrete railway sleepers are used in natural environment and exposed to static, cyclic and impact loads of different values and direction (vertical, horizontal, inclined) caused by train traffic (Thun, 2006; Rezaie, Shiri, \& Farnam, 2012; Taherinezhad, Sofi, Mendis, \& Ngo, 2013; Remennikov \& Kaewunruen, 2014). During service sleepers are also exposed to various atmospheric factors such as rainwater, freezing and thawing cycles, temperature variation, various chemical compounds in the soil and atmosphere, which can damage concrete structure and reinforcement and thus accelerate deterioration of sleeper (Figure 1).

Microcracking of concrete has been proven to be the initial damage leading to further deterioration of concrete structure (Shayan \& Quick, 1992; Mielenz, Marusin, Hime, \& Jugovic, 1995; Collepardi, 1999, 2003). The occurrence of microcracks during manufacturing of prestressed concrete sleepers is inevitable. Therefore, the initial stress of concrete appears during manufacturing of sleepers. The variety of technological processes (hardening of concrete, curing regime, pretensioning, method of prestress release) induce complicated stress state, which can lead to concrete cracking and further deterioration of concrete structure. The manufacturing technology of prestressed concrete shows that reinforcement draws-in to concrete during the prestress release. Therefore, the contact area between reinforcement and concrete is damaged at the end of prestressed concrete element allowing humidity and contaminated air $\left(\mathrm{CO}_{2}\right)$ penetrate into microcracks between reinforcement and concrete. This accelerates the development of chemical processes and formation of new chemical compounds in damaged zones of concrete that can induce expansion and further deterioration of concrete. Additionally, humidity and water penetrating into microcracks on the surface of concrete induce stresses in concrete or in the contact area between reinforcement and concrete under freezing temperatures. The deterioration of concrete structure is also accelerated by the impact of static and cyclic loads.

The deterioration of prestressed concrete sleepers usually starts at the ends of the sleeper (rail seat section and anchorage zone of reinforcement) (Mielenz et al., 1995; Sahu \& Thaulow, 2004; Ferdous \& Manalo, 2014), where the greatest technological defects occur (Jokūbaitis, Marčiukaitis and Valivonis, 2016). Therefore, it is very important to ensure the quality of technological processes during the manufacture of the sleepers and reduce the probability of occurrence of initial damage. 

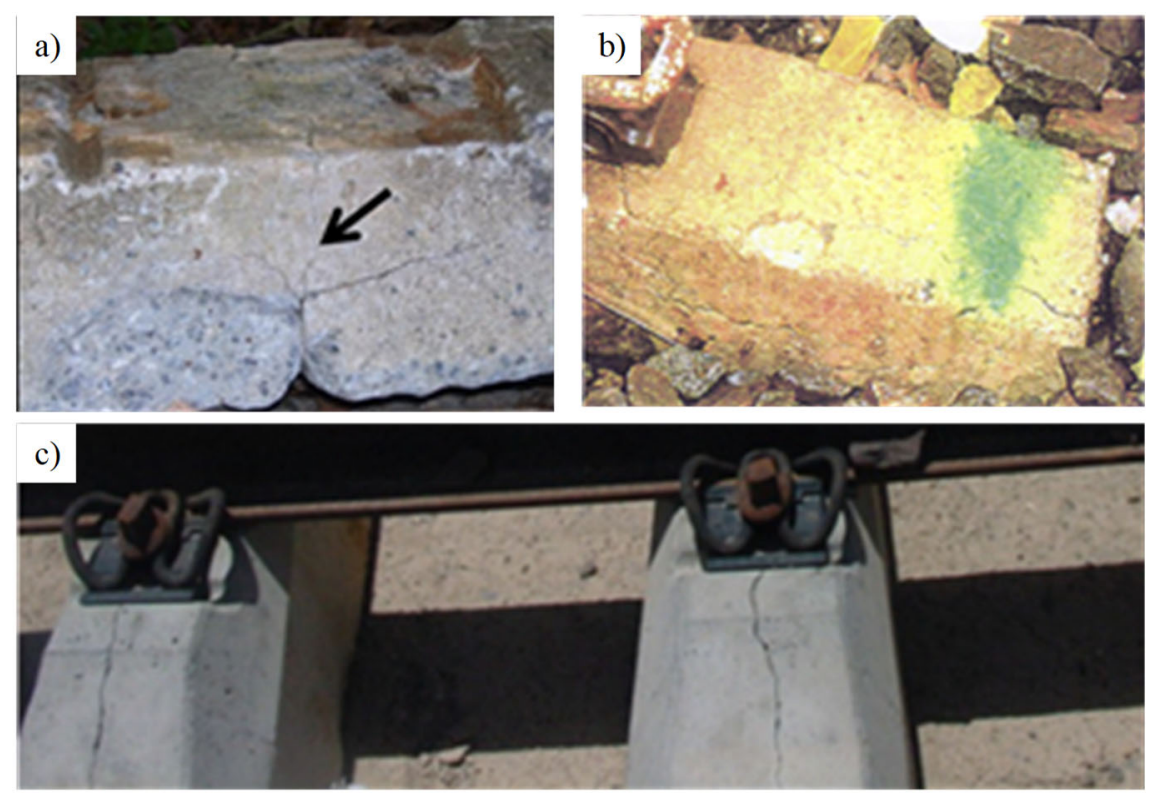

Figure 1. Cracking character of sleepers ends: a) (Zeman, Edwards, Lange, \& Barkan, 2010);

b) (Sahu \& Thaulow, 2004); c) (Rezaie et al., 2012)

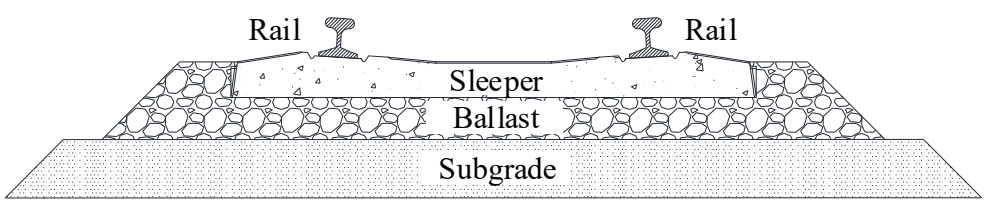

Figure 2. Structure of typical railway track

Prestressed concrete sleeper is a very important part of the railway (Figure 2), which has to ensure proper distance between the rails, withstand the loads transferred by the rails and gradually distribute them in the ballast, maintain an appropriate angle of rail inclination, serve as a rail support, restrain longitudinal, vertical and horizontal rail displacement, be resistant to abrasion and severe environmental conditions (heat, frost, humidity, temperature variation, chemical compounds). Therefore, for a more comprehensive identification of the causes of deterioration of prestressed concrete sleepers the research of concrete and sleepers manufactured according to the same technology need to be performed, assessing the influence of the above-mentioned factors on the character of deterioration and durability.

\section{Analysis of sleeper damages}

Microscopic and visual inspection of exploited and unexploited sleepers was performed. All sleepers were manufactured at the same time, in the same factory, using the same manufacturing technology. Part of the sleepers were exploited in railways for three years, and the other sleepers were stored in a factory territory for the same time. After a visual inspection it was determined that anchorage zone of some of exploited sleepers was damaged: cracked sleeper end, spall of concrete, uncovered reinforcement were visible (Figure 3). There was a residual crack in every rail seat section of exploited sleepers (Figure 3). After visual and microscopical inspection it was determined that there were microcracks around reinforcement at the end of some unexploited sleepers. The inspection showed that concrete damage and cracking around reinforcement at the ends of exploited sleepers were greater than in unexploited sleepers. This indicates that initial damage to concrete structure induced by technological impacts increases during service of sleepers. The contact area between reinforcement and concrete is damaged, and when a certain level of cracking is reached concrete can spall and initiate deterioration of sleeper.

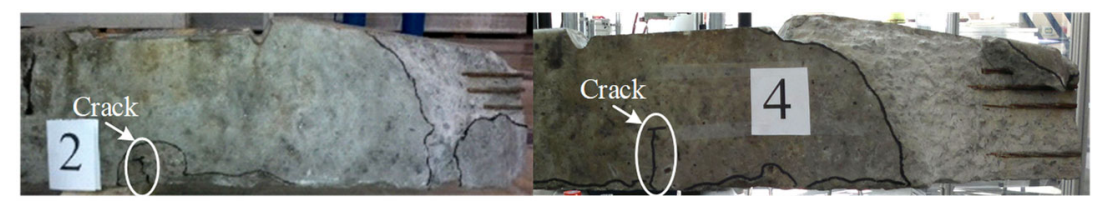

Figure 3. Damaged ends of exploited sleepers 
Sleepers were exposed not only to frost and humidity during service but also to aggressive substances (sulphates, $\mathrm{CO}_{2}$ ) in soil and air. These substances, together with water, are involved in chemical processes that lead to the formation of new chemical compounds in damaged concrete. This accelerates corrosion of reinforcement and development of concrete microcracking. As a result, larger microcracks formed at the interface between reinforcement and concrete at the ends of exploited sleepers compared to unexploited sleepers. There were no similar damages found in the middle parts of unexploited and exploited sleepers. Therefore, the research of rail support area was performed.

Due to the above-mentioned factors, the cracks in concrete structure, damaged interface between concrete and reinforcement, open pores and capillaries allows aggressive materials in air and water penetrate into concrete. Therefore, its interaction with chemical elements in cement create conditions for the formation of solid compounds that can induce destruction of concrete structure

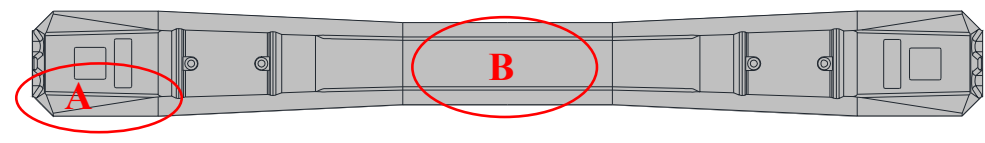

Figure 4. Sleeper and the sampling zones: A - at the end of the sleeper; B - in the middle of the sleeper

Therefore, the research of concrete structure of unexploited and exploited sleepers was performed with a scanning electron microscope (SEM) and the analysis of chemical composition was performed. Concrete samples were taken from the middle and at the end of the sleepers (Figure 4). The analysis of concrete structure showed that solid crystalline compounds have formed in microcracks and open pores at the ends of exploited sleepers (Figure 5a). The analysis of chemical composition showed that the chemical composition of new compounds matches secondary ettringite $3 \mathrm{CaO} \cdot \mathrm{Al}_{2} \mathrm{O}_{3} \cdot 3 \mathrm{CaSO}_{4} \cdot 32 \mathrm{H}_{2} \mathrm{O}$ (Figure $5 \mathrm{~b}$ ). Sulfate attack of reinforcement and concrete is induced by increased concentration of sulphates and it damages interface between reinforcement and concrete under the influence of frost and water. The products of sulfate attack (secondary ettringite) were not detected in samples taken from the middle of exploited sleepers (Figure 5d). The new compounds were not detected in the middle of unexploited sleepers (Figure $5 \mathrm{c}$ ).

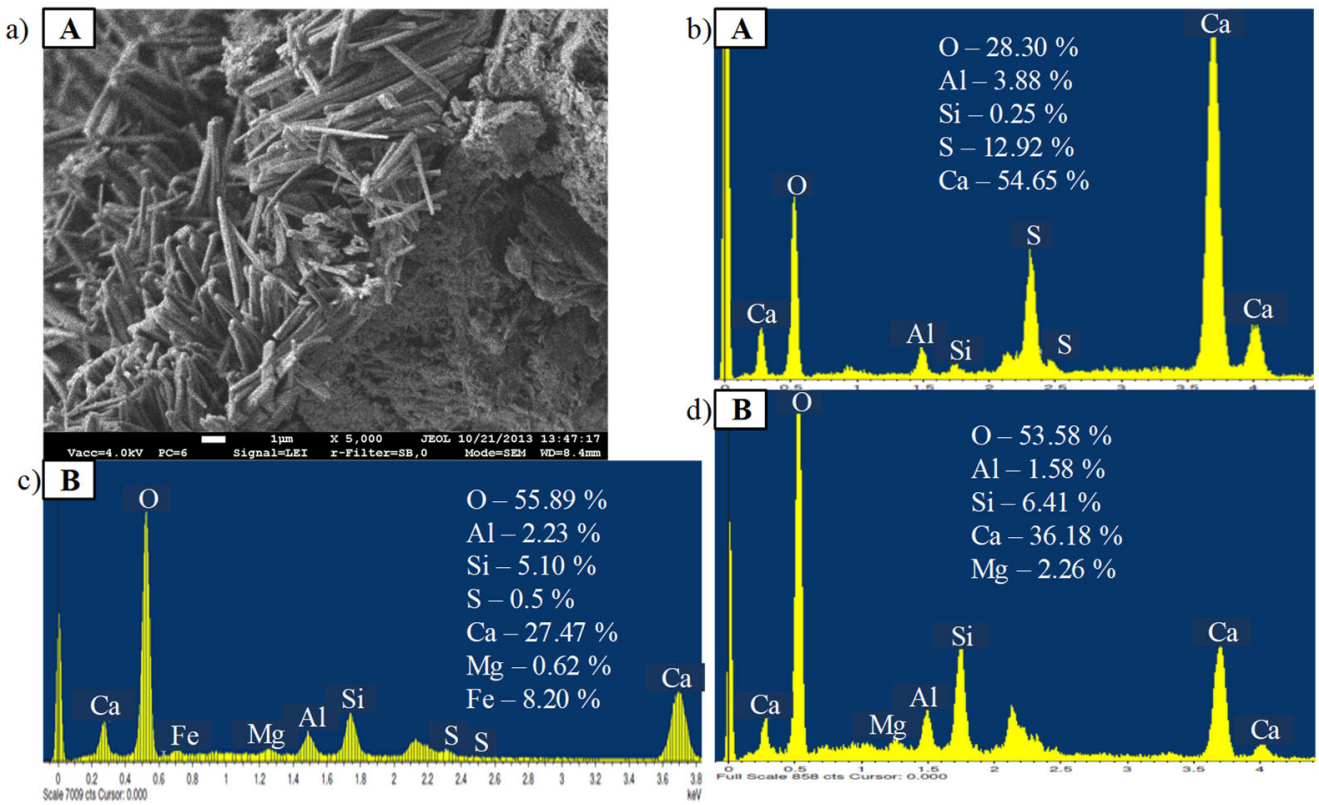

Figure 5. Analysis of the chemical composition of the samples taken from the sleepers: (a) crystals of secondary ettringite;

(b) the end of exploited sleeper; (c) middle of unexploited sleeper; (d) middle of exploited sleeper

The results of chemical composition of concrete samples taken from the sleepers are provided in Table 1. The analysis of chemical composition of concrete samples showed that there is a reduced amount of Si content at the ends of exploited sleepers. This indicates that humidity and water (rain, ground) leach out Si from concrete during service and concentration of chemicals in concrete redistributes. Additionally, an increased amount of sulphates ( $\mathrm{S}$ and $\mathrm{Al})$ were found at the ends of exploited sleepers (Table 1). These chemical elements, in the presence of O and external water, form compounds of sulphates that induce crystallization of secondary ettringite. Water is transported through capillaries in concrete, including various concrete imperfections (pores, voids, cracks, interface between aggregates and cement). These concrete imperfections are enriched (higher concentration) with water-borne substances, which can be the cause of the formation of secondary ettringite in voids that were previously filled with air or water. 
Table 1. Results of chemical analysis of concrete specimens

\begin{tabular}{|c|c|c|c|c|c|c|c|c|c|}
\hline Zones in tested sleeper & $\mathrm{O}, \%$ & $\mathrm{Al}, \%$ & $\mathrm{Si}, \%$ & $\mathrm{~S}, \%$ & $\mathrm{Ca}, \%$ & $\mathrm{Cu}, \%$ & $\mathrm{C}, \%$ & $\mathrm{Mg}, \%$ & $\mathrm{Fe}, \%$ \\
\hline \multirow{2}{*}{ The end of exploited sleeper } & 28.30 & 3.88 & 0.25 & 12.92 & 54.65 & - & - & - & - \\
\cline { 2 - 32 } & 53.78 & 5.33 & 0.39 & 7.94 & 22.89 & 2.33 & 7.34 & - & - \\
\hline Middle of exploited sleeper & 53.58 & 1.58 & 6.41 & - & 36.18 & - & - & 2.26 & - \\
\hline Middle of unexploited sleeper & 55.89 & 2.23 & 5.10 & 0.50 & 27.47 & - & - & 0.62 & 8.20 \\
\hline
\end{tabular}

The corrosion of reinforcement is induced by humid environment and water impacts. The formation of secondary ettringite at the interface between reinforcement and concrete and increased concentration of sulphates induce aggressive environment for reinforcement and accelerate the development of corrosion. The products of corrosion and freezing water induce expansion in concrete. Prestressed concrete sleepers exploited in natural environment are exposed to these impacts. Altogether it causes tensile stresses in concrete, which are increased by mechanical loads and determines the development and increase of microcracks.

\section{Experimental results}

The research of unexploited and exploited (damaged) sleepers was performed in the laboratory. All sleepers were produced at the same time in the same factory using the same production technology. The sleepers were reinforced with twelve pretensioned indented three wire steel strands (Figure 6b). The strands were pretensioned by a force equal to $70 \%$ of strand tensile strength $\left(0.7 f_{p}\right)$.

Concrete cubes $(100 \times 100 \times 100 \mathrm{~mm})$ were cut from the sleepers and a standard cubic $(150 \times 150 \times 150 \mathrm{~mm})$ concrete compressive strength was determined, which is greater than the design strength (C50/60). The mechanical properties of concrete and reinforcement are provided in Table 2 . The porosity of concrete according to water absorption was $3.3 \%$.

Table 2. Mechanical properties of concrete and reinforcement

\begin{tabular}{|c|c|c|c|c|c|c|c|c|}
\hline Parameters & $\begin{array}{c}f_{c m, \text { cube }}, \\
\mathrm{MPa}\end{array}$ & $\begin{array}{c}f_{c k, \text { cube }, \mathrm{MPa}} \\
(\mathrm{v}, \%)\end{array}$ & $\begin{array}{c}f_{c t m}, \\
\mathrm{MPa}\end{array}$ & $\begin{array}{c}f_{c t k}, \mathrm{MPa} \\
(\mathrm{v}, \%)\end{array}$ & $\begin{array}{c}E_{c m,}, \\
G P a\end{array}$ & $\begin{array}{c}f_{p}, \\
\mathrm{MPa}\end{array}$ & $\begin{array}{c}f_{p .0 .1,} \\
\mathrm{MPa}\end{array}$ & $\begin{array}{c}E_{p}, \\
\mathrm{GPa}\end{array}$ \\
\hline $\begin{array}{l}\text { Prestressed concrete } \\
\text { sleeper }\end{array}$ & 80.6 & $76.3(3.2)$ & 3.46 & $2.69(13.6)$ & 39 & 1935 & 1677 & 200.7 \\
\hline
\end{tabular}

$v$ - coefficient of variation, $f_{\text {ck.cube }}$ - characteristic cubic concrete compressive strength, $f_{\text {cm.cube }}-$ mean cubic concrete compressive strength.

Research of monoblock prestressed concrete sleepers was performed in accordance with (EN 13230-2, 2016a) and (EN 13230-2, 2016b). The object of the research was rail seat of the sleeper, therefore serviceability of the sleeper was monitored during static and dynamic tests at the rail seat section. The load was transferred through the metal plates and standard rubber pad to the centre of the rail seat section (Figure 6).

Residual crack width was measured at the rail seat section of the sleeper during the static and cyclic load tests. The crack width was measured at a distance of $15 \mathrm{~mm}$ from the bottom of the sleeper during all tests.

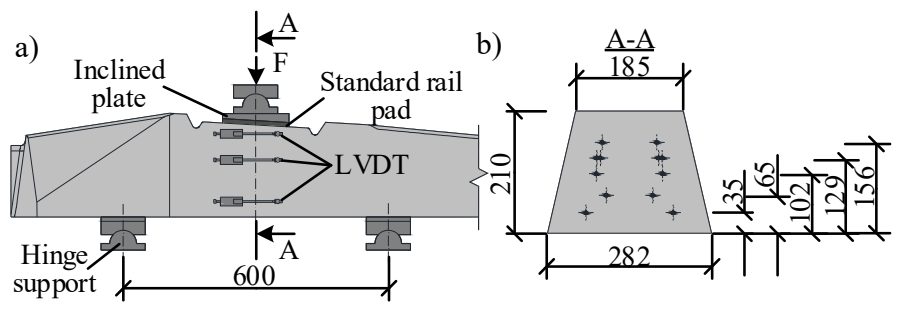

Figure 6. a) General view of test setup; b) cross-section of the rails seat

According to (EN 13230-2, 2016b) three reference static and dynamic loads must be satisfied during experimental tests of monoblock prestressed concrete sleeper: cracking load $\left(F_{c r}\right)$; maximum static $\left(F_{0.05 . s}\right)$ and dynamic $\left(F_{0.05 c}\right)$ test loads for which a crack width of $0.05 \mathrm{~mm}$ persist after removal of the load; maximum static $\left(F_{0.5 . s}\right)$ and dynamic $\left(F_{0.5 c}\right)$ test loads for which a crack width of $0.5 \mathrm{~mm}$ persist after removal of the load or static $\left(F_{R D . s}\right)$ and dynamic $\left(F_{R D . c}\right)$ failure loads.

All tested sleepers had the same geometric parameters. The sleepers are divided into two series: 2 pcs. of unexploited sleepers (US) and 5 pcs. of exploited sleepers (ES). 
According to (EN 13230-2, 2016b) three reference static loads $\left(F_{c r}, F_{0,05 s}, F_{0,5 s}\right.$ or $\left.F_{r B s}\right)$ must be satisfied during experimental tests of monoblock prestressed concrete sleeper. If at least one of these loads is not satisfied, the sleeper is considered unsuitable for service. At first static load is increased up to the load inducing first crack $\left(F_{c r . s}\right)$. After experimental cracking load is reached sleeper is unloaded. From this point, sleeper is loaded with static load increments of $10 \mathrm{kN}$ and unloaded after each load step. The static load test is continued in such a manner until failure.

The results of static load test at the rail seat section of sleeper are provided in Table 3. Experimental results show that experimental loads are higher than reference static cracking load $F_{c r}=149.6 \mathrm{kN}$ and reference residual crack width $(0.05 \mathrm{~mm}$ and $0.5 \mathrm{~mm})$ loads $F_{0.05 s}=269.3 \mathrm{kN}$ and $F_{0.5 s}=374 \mathrm{kN}$. Therefore, all tested sleepers meet requirement for reference loads (Table 3 ). All exploited sleepers had a residual crack at the rail seat section before the test. Therefore, no cracking load was determined. The reference residual crack width load $F_{0.05 s}$ of exploited sleepers is up to $12 \%$ higher compared to unexploited sleepers. This indicates that development of residual crack width up to $0.05 \mathrm{~mm}$ in exploited sleepers is slower. The residual crack width of unexploited sleepers did not reach $0.5 \mathrm{~mm}$ up to failure. Meanwhile, the residual crack width of $0.5 \mathrm{~mm}$ was reached almost in all tested exploited sleepers.

The development of crack width depends on the bond between reinforcement and concrete. The results of bond research after the influence of cyclic loading have shown that the bond strength between reinforcement and concrete has increased (Jokūbaitis, Marčiukaitis \& Valivonis, 2017; Jokūbaitis, Marčiukaitis, Valivonis, \& Strauss, 2018). It follows that the cyclic loading has affected the sleepers during exploitation in railway, and the development of crack widths was slower due to the increased bond comparing to the unexploited sleepers. This resulted in an increase of bearing capacity of exploited sleepers by $0-11 \%$ comparing to the unexploited sleepers tested under static loading.

Table 3. Test results of sleepers under static loading

\begin{tabular}{|c|c|c|c|c|c|c|c|}
\hline \multirow{3}{*}{ Series } & \multirow{3}{*}{ Specimen } & $\begin{array}{c}F_{0 s} \\
\left(M_{0 s}\right)\end{array}$ & $\begin{array}{c}F_{c r} \\
\left(M_{c r}\right)\end{array}$ & \multirow{2}{*}{$\begin{array}{c}F_{0.05 s} \\
\left(M_{0.05 s}\right) \\
>269.3 \\
(35.7)\end{array}$} & $\begin{array}{c}F_{0.5 s} \\
\left(M_{0.5 s}\right)\end{array}$ & $\begin{array}{c}F_{r B s} \\
\left(M_{r B s}\right)\end{array}$ & $\begin{array}{c}F_{R D s} \\
\left(M_{R D s}\right)\end{array}$ \\
\hline & & \multicolumn{2}{|c|}{$\begin{array}{c}>149.6 \\
(19.8)\end{array}$} & & \multicolumn{3}{|c|}{$\begin{array}{l}>374 \\
(49.6)\end{array}$} \\
\hline & & \multicolumn{6}{|c|}{ kN (kNm) } \\
\hline \multirow{2}{*}{ US } & US_1 & \multirow{7}{*}{$149.6(19.8)$} & $190(25.2)$ & $320(42.4)$ & - & $390(51.7)$ & $400(53.0)$ \\
\hline & US_2 & & $170(22.5)$ & $320(42.4)$ & - & $420(55.7)$ & $430(57.0)$ \\
\hline \multirow{5}{*}{ ES } & ES_1 & & - & $330(43.7)$ & $420(55.7)$ & $430(57.0)$ & $438,9(58.2)$ \\
\hline & ES_2 & & - & $360(47.7)$ & $430(57.0)$ & $430(57.0)$ & $440(58.3)$ \\
\hline & ES_3 & & - & $340(45.1)$ & $420(55.7)$ & $420(55.7)$ & $430(57.0)$ \\
\hline & ES_4 & & - & $310(41.1)$ & $420(55.7)$ & $420(55.7)$ & $420(55.7)$ \\
\hline & ES_5 & & - & $320(42.4)$ & - & $420(55.7)$ & $443,4(58.8)$ \\
\hline
\end{tabular}

$F_{0 s}$ - initial reference static test load, $F_{c r}-$ cracking load, $F_{0.05 s}$ and $F_{0.5 s}-$ maximum static test load for which a crack width of $0.05 \mathrm{~mm}$ and $0.5 \mathrm{~mm}$ respectively persist after removal of the load, $F_{r B s}$ - maximum static test load which cannot be increased, $F_{R D s}-$ static failure load.

The cyclic load test was performed in accordance with (EN 13230-2, 2016b). The cyclic load test of sleepers is divided into steps. At each step, sleeper is exposed to 5000 load cycles under the frequency of $5 \mathrm{~Hz}$. After each cyclic load step, the upper load level $\left(F_{\text {max.c }}\right)$ is increased by $20 \mathrm{kN}$, while maintaining a constant lower load limit $\left(F_{\text {min.c }}=50 \mathrm{kN}\right)$. The test is continued in such a manner up to failure. The crack width at the rail seat section was measured at every load step every 5000 load cycles. Measurements were taken in eleven load steps from 0 to 55000 load cycles.

The sleepers tested under cyclic load were divided in two series: 3 pcs. of unexploited sleepers (UC) and 5 pcs. of exploited sleepers (EC). The results of experimental research are provided in Table 4

According to (EN 13230-2, 2016b) sleeper must meet certain cracking requirements defined by the reference cyclic loads $\left(F_{c r}=149.6 \mathrm{kN}, F_{0.05 c}=224.4 \mathrm{kN}, F_{0.5 c}=329.1 \mathrm{kN}\right.$ or $\left.F_{r B c}=329.1 \mathrm{kN}\right)$. The results of cyclic load test show that all reference loads are satisfied and experimental loads are higher than those established in accordance with (EN 13230-2, 2016b) (Table 4).

The cyclic load inducing crack width of $0.05 \mathrm{~mm}$ in exploited sleepers is by $0-16 \%$ lower compared to unexploited sleepers (Table 4). This indicates that initial damage of exploited sleepers has a negative impact on the cracking of sleeper affected by cyclic loading. The decrease of bearing capacity of exploited sleepers up to $8 \%$ is conditioned upon the faster development of residual crack width and by the influence of cyclic loading. The cyclic loading accelerates the development of residual crack width comparing to the static loading. 
Table 4. Test results of sleepers under cyclic loading

\begin{tabular}{|c|c|c|c|c|c|c|c|}
\hline \multirow{3}{*}{ Series } & \multirow{3}{*}{ Specimen } & $\begin{array}{c}F_{0 c} \\
\left(M_{0 c}\right)\end{array}$ & $\begin{array}{c}F_{c r} \\
\left(M_{c r}\right)\end{array}$ & \multirow{2}{*}{$\begin{array}{c}F_{0.05 c} \\
\left(M_{0.05 c}\right) \\
>224.4 \\
(29.7)\end{array}$} & $\begin{array}{c}F_{0.5 c} \\
\left(M_{0.5 c}\right)\end{array}$ & $\begin{array}{c}F_{r B c} \\
\left(M_{r B c}\right)\end{array}$ & $\begin{array}{c}F_{R D c} \\
\left(M_{R D c}\right)\end{array}$ \\
\hline & & \multicolumn{2}{|c|}{$\begin{array}{c}>149.6 \\
(19.8)\end{array}$} & & \multicolumn{3}{|c|}{$\begin{array}{c}>329.1 \\
(43.6)\end{array}$} \\
\hline & & \multicolumn{6}{|c|}{$\mathrm{kN}(\mathrm{kNm})$} \\
\hline \multirow{3}{*}{$\mathrm{UC}$} & UC_1 & \multirow{8}{*}{$149.6(19.8)$} & $169.6(22.5)$ & $284.4(37.7)$ & - & $349.1(46.3)$ & $369.7(49.0)$ \\
\hline & UC_2 & & $169.6(22.5)$ & $284.4(37.7)$ & - & $349.1(46.3)$ & $370.1(49.0)$ \\
\hline & UC_3 & & $169.6(22.5)$ & $284.4(37.7)$ & - & $349.1(46.3)$ & $377.3(50.0)$ \\
\hline \multirow{5}{*}{$\mathrm{EC}$} & EC_1 & & - & $244.4(32.4)$ & - & $329.1(43.6)$ & $349.8(46.3)$ \\
\hline & EC_2 & & - & $284.4(37.7)$ & - & $329.1(43.6)$ & $351.8(46.6)$ \\
\hline & EC_3 & & - & $264.4(35.0)$ & - & $329.1(43.6)$ & $349.9(46.4)$ \\
\hline & EC_4 & & - & $244.4(32.4)$ & - & $329.1(43.6)$ & $349.5(46.3)$ \\
\hline & EC_5 & & - & $284.4(37.7)$ & - & $329.1(43.6)$ & $350.3(46.4)$ \\
\hline
\end{tabular}

$F_{0 c}$ - initial reference cyclic test load, $F_{c r}$ - cracking load, $F_{0.05 c}$ ir $F_{0.5 c}$ - maximum cyclic test load for which a crack width of $0.05 \mathrm{~mm}$ and $0.5 \mathrm{~mm}$ respectively persist after removal of the load, $F_{r B c}$ - maximum cyclic test load which cannot be increased, $F_{R D c}-$ cyclic failure load.

\section{Conclusions}

The most vulnerable zones of prestressed concrete sleepers are the rail seat section and the reinforcement anchorage zone. The end cracking of sleeper is conditioned upon various impacts acting during sleeper production and service stages. Several mutually dependent impacts are usually the cause of cracking, therefore the determination of failure causes of sleeper is a complex task.

Usually, research of unexploited and for some time in railway exploited sleepers are performed separately. Unique research of cracking of unexploited and exploited (damaged) for three years in railway sleepers produced at the same time is presented in this work. All sleepers tested were of the same age.

The results of research at microscopic level of chemical composition of concrete structure showed that sulphate corrosion in reinforcement and concrete has started at the ends of exploited sleepers. Delayed ettringite formation and an increase of sulphate concentration at the interface between reinforcement and concrete create an aggressive environment for reinforcement and together with other environmental impacts (water, frost) contributes to deterioration of this zone.

All tested sleepers met cracking and bearing capacity requirements even though some of exploited sleepers were severely damaged. Nevertheless, uncovered reinforcement at the ends of exploited sleepers and residual cracks at the rail seat section must be considered as potential impact for lowering stiffness and durability of sleepers.

The research has revealed that reinforcement at the ends of the sleepers must be protected from the humidity and other environmental impacts, regular inspection of the sleepers should be performed. Additionally, research of chemical composition of cement and aggregates should be performed every time when mining site of materials is changing and regularly - when materials are transported from the same quarries.

\section{Acknowledgements}

Authors are grateful to Applied Laboratory of Buildings, Constructions and Materials of Vilnius Gediminas Technical University for equipment and infrastructure, which were employed for investigation.

\section{References}

Collepardi, M. (1999). Damage by delayed ettringite formation. Concrete International, 21(1), 69-74.

Collepardi, M. (2003). A state-of-the-art review on delayed ettringite attack on concrete. Cement and Concrete Composites, 25(45), 401-407. https://doi.org/10.1016/S0958-9465(02)00080-X

Eupopean Committee for Standartization. (2016a). Railway applications. Track. Concrete sleepers and bearers. Part 1: General requirements (EN 13230-1).

Eupopean Committee for Standartization. (2016b). Railway applications. Track. Concrete sleepers and bearers. Part 2: Prestressed monoblock sleepers (EN 13230-2).

Ferdous, W., \& Manalo, A. (2014). Failures of mainline railway sleepers and suggested remedies - Review of current practice. Engineering Failure Analysis, 44, 17-35. https://doi.org/10.1016/j.engfailanal.2014.04.020 
Jokūbaitis, A., Marčiukaitis, G., \& Valivonis, J. (2016). Influence of technological and environmental factors on the behaviour of the reinforcement anchorage zone of prestressed concrete sleepers. Construction and Building Materials, 121, 507-518. https://doi.org/10.1016/j.conbuildmat.2016.06.025

Jokūbaitis, A., Marčiukaitis, G., \& Valivonis, J. (2017). Analysis of reinforcement anchorage zone behavior of prestressed concrete elements under static and cyclic loads. Procedia Engineering, 172, 457-464. https://doi.org/10.1016/j.proeng.2017.02.028

Jokūbaitis, A., Marčiukaitis, G., Valivonis, J., \& Strauss, A. (2018). Influence of cyclic loading and frost on the behavior of bond of three-wire strand. Structural Concrete, 19(5), 1363-1375. https://doi.org/10.1002/suco.201700245

Mielenz, R. C., Marusin, S. L., Hime, W. G., \& Jugovic, Z. T. (1995). Investigation of prestressed concrete railway tie distress. Concrete International, 17(12), 62-68.

Remennikov, A. M., \& Kaewunruen, S. (2014). Experimental load rating of aged railway concrete sleepers. Engineering Structures, 76, 147-162. https://doi.org/10.1016/j.engstruct.2014.06.032

Rezaie, F., Shiri, M. R., \& Farnam, S. M. (2012). Experimental and numerical studies of longitudinal crack control for pre-stressed concrete sleepers. Engineering Failure Analysis, 26, 21-30. https://doi.org/10.1016/j.engfailanal.2012.07.001

Sahu, S., \& Thaulow, N. (2004). Delayed ettringite formation in Swedish concrete railroad ties. Cement and Concrete Research, 34(9), 1675-1681. https://doi.org/10.1016/j.cemconres.2004.01.027

Shayan, A., \& Quick, G. W. (1992). Microscopic features of cracked and uncracked concrete railway sleepers. ACI Materials Journal, 89(4), 348-361. https://doi.org/10.14359/2560

Taherinezhad, J., Sofi, M., Mendis, P. A., \& Ngo, T. (2013). A review of behaviour of prestressed concrete sleepers. Electronic Journal of Structural Engineering, 13(1), 1-16.

Thun, H. (2006). Assessment of fatigue resistance and strength in existing concrete structures. Luleå University of Technology, Sweden.

Zeman, J. C., Edwards, J. R., Lange, D. A., \& Barkan, C. P. L. (2010). Hydraulic mechanisms of concrete-tie rail-seat deterioration. In William W. Hay Seminar (pp. 1-45). University of Illinois at Urbana-Champaign, USA. 